3. Inshyn M. I. Trudove parvo Ukrainy [Labor law of Ukraine]. pidruchnyk / za zahalnoiu redaktsiieiu M. I. Inshyna, V. L. Kostiuka, V. P. Melnyka. Vyd. 2-he, pererob. i dop. Kyiv: Tsentr uchbovoi literatury

2016. 472 s. (in Ukrainian)

4. Kukhnyuk D.V., Shylenko B. Dystsyplinarn vidpovidalnist za porushennia advokatskoi etyky [DISCIPLINARY LIABILITY FOR VIOLATION OF LEGAL ETHICS]. visnyk Kyivskoho natsionalnoho universytetu imeni Tarasa Shevchenka. Seriia "Yurydychni nauky" 2019. №4. S.31-34 (in Ukrainian)

5. Pravy'la advokats'koyi ety'ky' zatverdzheni Zvitno-vy'borny'm z'yizdom advokativ Ukrainy' vid 9 chervnya 2017 roku. [The rules of lawyer's ethics were approved by the Reporting and Election Congress of Lawyers of Ukraine dated June 9, 2017]. URL: http://unba. org.ua/assets/uploads/ legislation/pravila/2017-06-09-pravila-2017_596f00dda53cd.pdf (in Ukrainian). 6. Kryminalnyi protsesualnyi kodeks Ukrainy: Zakon Ukrainy vid 9 chervnia 2017 roku. $\mathrm{Zi}$ zminamy vid 20.04.2020. URL: https://zakon.rada.gov.ua/laws/show/4651-17] (in Ukrainian)
7.Pro zapobihannia koruptsii: Zakon Ukrainy vid 14.10.2014. Zi zminamy vid 19.04.2020. URL:https://zakon.rada.gov.ua/laws/card/1700-18 (in Ukrainian)

8. Yedynyi Derzhavnyi reiestr sudovykh rishen. URL: http://reyestr.court.gov.ua/ ( in Ukrainian)

9. Zaborovskyi V.V., Bysaha Y. M., Buletsa S. B. Pravovyi status advokata: problemy teoriyi ta praktyky [Law status of an advicaye: issues of theory and practice]. - Uzhhorod: Vydavnychyi dim "Helvetyka", 2019. 650s. (in Ukrainian)

10. Zaborovskyi V.V. Pravovyi status advokata $v$ umovakh stanovlennia nezalezhnoi advokatury Ukrainy [Law status of an advocate in the conditions of the formation of independent legal practice of Ukraine ]. Uzhhorod: Vydavnychyi dim "Helvetyka", 2017. 900s.

Received: $15 / 05 / 2020$ 1st Revision: $07 / 06 / 2020$ Accepted: 24/06/2020

M. Panchenko, Dr. of Law, Teaching Assistant

Taras Shevchenko National University of Kyiv, Kyiv, Ukraine

\title{
THE ADVOCATE'S DISCIPLINARY RESPONSIBILITY FOR WRONGFUL COOPERATION WITH LAW-ENFORCEMENT BODIES
}

This article is devoted to the research on the concept and features of the advocate's wrongful cooperation with law-enforcement bodies and the circumstances that influence the severity of a disciplinary penalty in the result of such cooperation. A list of certain features is given to distinguish the lawful cooperation of an advocate with law-enforcement bodies from the wrongful one, which leads to bringing the advocate to the disciplinary responsibility. The author ascertains the forms in which the wrongful cooperation of an advocate and law-enforcement bodies may occur. The article determines that law-enforcement bodies often use the information that an advocate possesses due to his/her special professional status in order to perform their functions. Besides, the article examines the possibility for an advocate to be a whistleblower under the Law of Ukraine on Prevention of Corruption. The article also analyzes the decision of the Supreme Court in the administrative case where the decision of the Higher Qualification and Disciplinary Bar Commission (HQDB) on bringing the advocate to the disciplinary responsibility and imposing a disciplinary penalty of depriving him the right to advocacy for a wrongful cooperation with law-enforcement bodies is appealed. In this research the attention is paid to the wrongdoer's arguments and the corresponding legal position of the Supreme Court which, having used the acts of the national legislation, determined advocate's actions to be illegal and denied the claimant's demands.

The author defines the category of a "wrongful cooperation of an advocate with law-enforcement bodies", determines its features, and suggests the ways for improving the effectiveness of bringing wrongdoers to the disciplinary responsibility in case of such cooperation.

Keywords: a disciplinary offence, a disciplinary penalty, a confidant, a whistleblower, secret investigatory (inquiry) operations, tracking measures.

Bulletin of Taras Shevchenko National University of Kyiv. Legal Studies, 2020; 2 (113): 47-55

УДК: 342.9

DOI: https:doi.org/10.17721/1728-2195/2020/2.113-10
ISSN 1728-2195

C Taras Shevchenko National University of Kyiv Publishing center "Kyiv University", 2020

М. Плескач, асп.

Київський національний університет імені Тараса Шевченка, Київ, Україна

\section{СПІВВІДНОШЕННЯ ЖИТТЄВО ВАЖЛИВИХ ІНТЕРЕСІВ ЛЮДИНИ, СУСПІЛЬСТВА ТА ДЕРЖАВИ У КОНТЕКСТІ АДМІНІСТРАТИВНО-ПРАВОВОГО ЗАБЕЗПЕЧЕННЯ КІБЕРНЕТИЧНОӤ БЕЗПЕКИ}

Розелянуто основні підходи до розв'язання проблеми збалансування життєво важливих інтересів людини, суспільства та держави при використанні кібернетичного простору засобами адміністративного права. Визначено юридичну сутність і значення співвідношення життєво важливих інтересів людини, суспільства та держави в контексті адміністративно-правового забезпечення кібернетичної безпеки, зокрема належного балансу між правоохоронними інтересами держави і повагою до основних прав людини.

При дослідженні використано такі методи: аналізу - для з'ясування окремих ознак понять "інтерес", "потреба", "суб'єктивне право"; синтезу - при виведенні узагальнених понять, зокрема "інтерес людини при використанні кіберпростору"; порівняльно-правовий - для зіставлення законодавства України та міжнародного законодавства у досліджуваному питанні; класифікації - для визначення можливих життєво важливих прав та інтересів людини у кібернетичному просторі.

Окреслено можливу структуру кібернетичної безпеки людини через сукупність ї̈ важливих прав та інтересів у кібернетичному просторі, серед яких: право на доступ до мережі Інтернет (або на широкосмуговий зв'язок); право на захист персональних даних під час використання кіберпростору; право на захист від агресивних маркетингових технологій у кіберпросторі, заборона спостереження та (або) моніторингу, у тому числі через файли "соокіе", маркери HTTP, HTML5, веб-маяки чи інші технології; право на освіту й на доступ до знань за допомогою використання кіберпростору та ін.

Висновки та пропозиції, викладені у дослідженні, можуть бути використані для вдосконалення спеціальних норм адміністративного та інформаційного законодавства України, зокрема Закону України "Про основні засади забезпечення кібербезпеки України".

Ключові слова: баланс інтересів людини, суспільства та держави; використання кібернетичного простору; публічний інтерес; приватний інтерес.

ВСТУП. Актуальність проблематики. В умовах суттєвого збільшення ролі інформаційних технологій у житті людей, невпинного збільшення їх частки у валовому внутрішньому продукті України, особливо під час криз, епідемій та конфліктів, забезпечення належних безпекових правових, організаційних, технічних основ при використанні таких технологій в інтересах людини, держави, суспільства $€$ надзвичайно важливим питанням. Без сумніву, належний рівень безпеки $є$ однією із базових потреб і відіграє важливу роль у забезпеченні 
впорядкованості повсякденного життя, у тому числі під час використання кібернетичного простору. Однак забезпечення кібербезпеки без дотримання принципу пропорційності, який передбачає збереження справедливої рівноваги (балансу) між інтересами держави, суспільства та людини, може призвести до серйозних соціально-правових конфліктів. Отже, виникає необхідність дослідження того, яким чином можуть співвідноситись між собою життєво важливі інтереси різних рівнів - людини, суспільства та держави у контексті адміністративно-правового забезпечення кібернетичної безпеки.

Постановка проблеми. У період із 2016 по 2019 роки Україною було здійснено певні кроки, спрямовані на впорядкування суспільних відносин, які виникають у процесі використання кібернетичного простору, зокрема прийнято низку важливих нормативноправових актів у цій галузі, таких як-от: Указ Президента України від 15 березня 2016 року за № 96/2016 про рішення Ради національної безпеки і оборони України від 27 січня 2016 року "Про Стратегію кібербезпеки України" [1], Закон України "Про основні засади забезпечення кібербезпеки України" від 5 жовтня 2017 року за № 2163-VIII [2], Указ Президента України від 25 лютого 2017 року за № 47/2017 про рішення Ради національної безпеки і оборони України від 29 грудня 2016 року "Про Доктрину інформаційної безпеки України" [3] та ін.; створено центральний орган виконавчої влади, який відповідає за формування та реалізацію державної політики у сорері цифровізації, відкритих даних, національних електронних інформаційних ресурсів, інтероперабельності; удосконалено систему цифрової освіти, оновлено відповідні освітні та навчальні програми, а також проведено певні наукові дослідження у цьому напрямі.

Однак, керуючись аналізом нормативно-правової бази, аналітичних звітів профрільних фрахівців, відповідної наукової літератури, можемо констатувати, що нині, на жаль, проблема співвідношення і балансу життєво важливих інтересів людини, суспільства та держави у контексті адміністративно-правового забезпечення кібернетичної безпеки залишилась поза науковою увагою.

Мета та об'єкт дослідження. 3 огляду на вищевикладене, метою цього дослідження є визначення юридичної сутності та значення співвідношення життєво важливих інтересів людини, суспільства та держави у контексті адміністративно-правового забезпечення кібернетичної безпеки, зокрема належного балансу між правоохоронними інтересами держави і повагою до основних прав людини.

Об'єктом дослідження $є$ життєво важливі інтереси людини, суспільства, держави як правові категорії, а також їх співвідношення.

Методи дослідження. Методологічною основою цього дослідження стали методи аналізу, зокрема при дослідженні окремих ознак понять "інтерес", "потреба", "суб'єктивне право"; синтезу для виведення узагальненого поняття "інтерес людини під час використання кіберпростору", "інтерес держави, суспільства під час використання кіберпростору"; порівняльно-правовий метод у процесі зіставлення законодавства України та міжнародного законодавства у досліджуваному питанні. За допомогою методу класифікації було визначено можливі життєво важливі права та інтереси людини у кібернетичному просторі.

ВИКЛАД ОСНОВНОГО МАТЕРІАЛУ. Аналіз досліджень і публікацій. Серед фахівців з адміністративного та інформаційного права, наукові роботи яких присвячені окремим аспектам захисту життєво важливих інтересів людини, суспільства та держави, варто виокремити праці Авер'янова В. Б., Баранова О. А., Бевзен- ка В. М., Берлача А. І., Бєлякова К. І., Діхтієвського П. В., Довганя О. В., Заярного О. А., Золотар О. О., Мельника Р. С., Ткачука Т. Ю. та ін. Однак, попри наявні наукові розвідки, більш детального вивчення заслуговує недосліджена раніше частина загальної проблематики інформаційного права, а саме - напрями та способи збалансування часто конкуруючих інтересів людини, суспільства та держави у контексті адміністративно-правового забезпечення кібернетичної безпеки.

Наукова дискусія. Сучасні наукові дослідження поняття "безпека" тлумачать переважно як стан, коли кому-небудь або чому-небудь ніщо не загрожує. У свою чергу, у загальноюридичному тлумаченні поняття "безпека" визначається як стан захищеності життєво важливих інтересів особи, суспільства і держави від зовнішньої та внутрішньої загрози, зокрема у таких нормативно-правових актах, як Закон України "Про національну безпеку України" [4], Закон України "Про Основні засади розвитку інформаційного суспільства в Україні на 20072015 роки" [5], Закон України "Про основні засади забезпечення кібербезпеки України" [2] з уточненням на відповідну сореру правового регулювання.

На нашу думку, поняття "безпека" $€$ полісемантичним, комплексним, має надгалузевий характер, залежить від великої кількості факторів і навряд чи може бути використане поза конкретним контекстом.

У зв'язку із запровадженням людиноцентристської концепції в адміністративно-правовій доктрині в Україні, переглядом змісту методів адміністративного права і зважаючи на вагому роль безпеки людини у кібернетичному просторі, суспільні відносини у цій сфері потребують належного забезпечення як державою, органами місцевого самоврядування, так і недержавними суб'єктами.

У ст. 1 Закону України "Про основні засади забезпечення кібербезпеки України" [2] визначено, що кібербезпека - це захищеність життєво важливих інтересів людини і громадянина, суспільства та держави під час використання кіберпростору, за якої забезпечується сталий розвиток інформаційного суспільства та цифрового комунікативного середовища, своєчасне виявлення, запобігання і нейтралізація реальних і потенційних загроз національній безпеці у кіберпросторі. При цьому вказаний закон чи інший профільний нормативно-правовий акт мають здебільшого декларативний характер і містять нечіткі норми, які не можуть забезпечити ефективного функціонування системи кібербезпеки в Україні.

Наприклад, зі змісту норм Закону України "Про основні засади забезпечення кібербезпеки України" незрозуміло, яким чином узгоджуються різні структурні елементи (рівні) забезпечення кібернетичної безпеки між собою (держави, людини й суспільства), а також про які саме життєво важливі інтереси йдеться у цьому законі. Не йдеться у згаданому нормативно-правовому акті й про сутність та ознаки цього правового явища.

Відсутність розуміння, що саме потрібно вважати життєво важливими інтересами людини, держави й суспільства під час використання кібернетичного простору, брак базових критеріїв розмежування життєво важливих інтересів людини, держави й суспільства зумовлює те, що об'єкт правового регулювання - правовідносини, які виникають у зв'язку з реалізацією відповідних прав, інтересів та обов'язків, стає нечітким, що, у свою чергу, призводить до труднощів при розмежуванні компетенції суб'єктів забезпечення кібербезпеки за предметними і функціональними критеріями [6, с. 36]. Зокрема, в одних випадках такий стан речей призводить до перевищення службових повноважень відповідними суб'єктами, а в інших - до службової недбалості. 
На практиці досить часто інтереси одного суб'єкта кібербезпеки можуть суперечити інтересам іншого, порушуючи відповідний баланс. Зокрема, нині в Україні спостерігається превалювання правоохоронних інтересів держави над повагою до основних прав людини у кібернетичному просторі.

Прикладом може служити обмеження у 2017 році українськими інтернет-провайдерами доступу до низки російських веб-ресурсів, зокрема "ВКонтакті", "Однокласники", "Mail.ru", "Яндекс", "Лабораторія Касперського", "Dr.Web", офріційного дистриб'ютора "1C" на території України тощо на підставі Указу Президента України за № 133/2017 від 15 травня 2017 року про введення в дію рішення РНБО України від 28 квітня 2017 року "Про застосування персональних спеціальних економічних та інших обмежувальних заходів (санкцій)" [7]. Зазначущо, що в умовах інформаційної та збройної агресії проти України це, мабуть, був цілком обґрунтований крок, однак, зважаючи на структуру, принципи побудови кіберпростору, наявність технології віртуальної приватної мережі (VPN - virtual private network), TOR (The Onion Router) як вільного і відкритого програмного забезпечення для реалізації другого покоління багатошарової маршрутизації, - лише частково ефективний.

Доречно звернути увагу на той факт, що державою не було на той час проведено належної діяльності, спрямованої на пошук альтернативи забороненому російському програмному забезпеченню та веб-ресурсам. При цьому однією із обов'язкових і важливих умов забезпечення кібербезпеки має бути дотримання принципу пропорційності, який передбачає збереження справедливої рівноваги (балансу) між інтересами держави (суспільства), пов'язаними із певним втручанням (наприклад обмеження доступу людини до якогось вебсайту), та інтересами особи, яка так чи інакше страждає від такого втручання. Як зазначає Верховний Суд України у своїй Постанові від 16 грудня 2015 року у справі за № 6-2510 цс 15, "справедлива рівновага" передбачає наявність розумного співвідношення (обґрунтованої пропорційності) між метою, що передбачається для досягнення, і засобами, які використовуються. Необхідний баланс не буде дотриманий, якщо особа несе "індивідуальний і надмірний тягар" [8]. Публічні та приватні інтереси мають бути збалансованими, навіть у випадках їх мінімальної змістовної погодженості, і тільки в такому разі можна стверджувати про ефективність правового регулювання суспільних відносин [10, с. 56]. Із цього випливає, що колективна безпека у державі має забезпечуватись не на шкоду фундаментальним природним правам і свободам людини.

Ще одним важливим принципом забезпечення кібербезпеки має бути принцип законності, сутність якого полягає в тому, що нормативно-правовий акт, який регулює питання забезпечення колективної безпеки, у тому числі кібернетичної, має бути доступним для заінтересованих осіб, чітким і передбачуваним у питаннях застосування та наслідків дії його норм, бути необхідним, а також пропорційним у демократичному суспільстві й забезпечувати ефективні засоби правового захисту [9].

3 огляду на це важливим науковим завданням $є$ допомога у конкретизації життєво важливих прав та інтересів людини, держави й суспільства під час використання кібернетичного простору.

Передусім для здійснення узагальнення та синтезу понять "інтерес людини, держави, суспільства під час використання кібернетичного простору" доречно проаналізувати вихідне основоположне поняття - "інтерес", а також його відмінність від "суб'єктивного права" чи "потреби".
Можемо погодитись із думкою Первомайського О. О. про те, що інтерес має значення і впливає на різногалузеві правовідносини та діяльність учасників правовідносин, а також окремі правові явища, інститути, систему права в цілому [10, с. 53].

Наукова юридична література містить різні підходи до розуміння поняття "інтерес". Дослідниками "інтерес" розглядається крізь призму різних аспектів, підходів, як у широкому тлумаченні, так і вузькому, як об'єктивна категорія, так і суб'єктивна, а також як френомен, що має об'єктивні й суб'єктивні характеристики [11, с. 218].

Як зазначає Харитонов $€$. О., відповідно до концепції українського цивільного законодавства інтересом можна вважати прагнення, устремління, потреби особи, які не визначені законом або угодою сторін як цивільні права, але спрямовані на виникнення або збереження останніх. На думку цього вченого, саме при такому розумінні сутності поняття "інтерес" $є$ можливою постановка питання про дослідження проблеми узгодження, протиставлення та конфллікту інтересів [11, с. 220].

Дещо іншої думки дотримується Первомайський О. О., який зазначає, що інтерес у максимально чіткому розумінні його змісту та суті $€$ ні благом, ні потребою, ні ціллю. Під інтересом, на його думку, може розумітися правова цінність, що змістовно є усвідомленою учасником правовідносин юридично забезпеченою в реалізації та захисті можливість отримання певного права чи іншого блага [10, с. 54]. У свою чергу, Венедіктова І. В. вважає, що охоронюваний законом інтерес це усвідомлене суб'єктом права домагання отримати певне матеріальне (нематеріальне) благо або змінити правовий статус, що спонукає суб'єктів права вчиняти конкретні дії чи, навпаки, утримуватися від них, перебуває в правовому полі та забезпечене в реалізації підтримкою держави, здійснюється у формі дозволу й відбивається в конкретних правовідносинах [12, с. 21].

Цікавою, хоча і дещо суперечливою, на наш погляд, $€$ думка Самбора М. А., який зазначає, що інтерес- це спрямованість суб'єкта, а не його можливість, що підкреслює значущість внутрішнього фрактору щодо його реалізації; інтерес у праві - це спрямованість суб'єкта, обумовлена його внутрішнім переконанням у оволодінні певним благом матеріального чи нематеріального характеру, що $€$ задоволенням потреби, здійснення та реалізація якого відбувається в межах загальноприйнятих правил поведінки, визначених у нормах права, що відповідає відсутності прямої заборони в досягненні такого блага, так і бажаним для нього способом, а також спирання на забезпечення компетентними органами у разі наявності перешкоди на шляху можливості його задоволення [13, с. 11-12]. Ми не можемо повністю погодитись із таким визначенням, адже при реалізації інтересу недостатньо внутрішньої спрямованості суб'єкта, потрібна також наявність умов, сприятливих для його реалізації, обставин, які допомагають у такій реалізації, тобто це і $є$ фактично можливість [14].

Як влучно зазначає Заярний О. А. у контексті правового забезпечення розвитку інформаційної сфери України, соціальна цінність елементів інформаційної сфери зумовлюється декількома факторами, у тому числі здатністю задовольняти правомірні інтереси та потреби членів інформаційного суспільства під час реалізації ними суб'єктивних прав і юридичних обов'язків [15, с. 28]. Тобто поняття інтересу, потреб і суб'єктивних прав цим дослідником не ототожнюються. Такий підхід, на нашу думку, є достатньо виваженим, якщо розглядати потребу як певну необхідність у чому-небудь, що вимагає задоволення [16], а інтерес як ширшу правову категорію, а саме юридично забез- 
печену в реалізації та ії̈ захисті можливість отримання певного права. Із цього випливає, що інтерес за природою не можна вважати ні квазісуб'єктивним правом, ні потребою. Однак при цьому суб'єктивне право не протиставляється інтересу, навпроти, суб'єктивне право представляє юридичну можливість здійснення інтересу. Тобто суб'єктивне право не може виникнути без дійсного інтересу, майнового чи морального. Якщо такий інтерес існував у момент визначення правовідношення, але згодом відпав, то разом із ним припиняється і суб'єктивне право [17, с. 197-198].

Розглянувши розуміння інтересу з погляду приватного права, на нашу думку, доречно звернутися до тлумачення цієї юридичної категорії з погляду права публічного, зокрема адміністративного. Галунько В.В.вважає, що під публічним інтересом варто розуміти важливі для значної кількості фрізичних і юридичних осіб потреби, які відповідно до законодавчо встановленої компетенції забезпечуються публічною адміністрацією [18, c. 181]. Тобто автор цього визначення фактично визначає інтерес через потреби. Пришва Н. Ю. дотримується думки, що публічний інтерес - це визнаний державою і забезпечений правом інтерес соціальної спільноти, задоволення якого $€$ умовою та гарантією її існування i розвитку [19, с. 63]. Коломоєць Т. О. вважає, що публічним інтересом варто вважати певну сукупність приватних інтересів, адже множина приватних інтересів на певному етапі розвитку суспільства за законом діалектики взаємного переходу кількісних і якісних змін переростає в публічний інтерес [20]. Однак останнє визначення не містить чітких критеріїв розмежування публічного (держава, суспільство) і приватного (людина) інтересів. Також не зрозуміло, яким чином усувається проблема повної або часткової незбіжності інтересів не лише різних рівнів (людина, суспільство, держава), а й одного рівня (конкуруючі інтереси різних людей тощо), і як при цьому останні можуть транссормуватися у злагоджений публічний інтерес. Крім того, як зазначає Конституційний Суд України у своєму рішенні від 8 квітня 1999 року за № 3-рп/99 у справі про представництво прокуратурою України інтересів держави в арбітражному суді (справа № 1-1/99), інтереси держави відрізняються від інтересів інших учасників суспільних відносин, адже в основі перших завжди $€$ потреба у здійсненні загальнодержавних (політичних, економічних, соціальних тощо) дій, програм, спрямованих на захист суверенітету, територіальної цілісності, державного кордону України, гарантування ії державної, економічної, інфоормаційної, екологічної безпеки, охорону землі як національного багатства, захист прав усіх суб'єктів права власності та господарювання тощо [21].

Цікавим $є$ нижчезазначений підхід до розв'язання вказаної проблеми, із яким ми можемо погодитись. Зокрема, до критеріїв відмежування публічного інтересу від приватного можна віднести такі [22, с. 25]:

1) які саме цінності $€$ об'єктом правовідносин: $у$ публічному інтересі - усього суспільства, держави, у приватному - окремих людей;

2) суб'єктами забезпечення у публічному інтересі виступають суб'єкти публічної адміністрації; приватний інтерес зазвичай забезпечується самими приватними суб'єктами права;

3) ступінь правової регламентації публічного інтересу перебуває на високому рівні, а також діє принцип, закладений у ст. 19 Конституції України, згідно з яким органи державної влади та органи місцевого самоврядування, їхні посадові особи зобов'язані діяти лише на підставі, у межах повноважень та у спосіб, що передбачені Конституцією України та законами України [25]; у свою чергу, приватні інтереси повною мірою не піддаються державно-юридичному регулюванню;

4) юридична природа об'єкта посягання у публічному інтересі виражається суспільною небезпекою, а у приватному - суспільною шкодою;

5) захист публічних прав та інтересів здійснюється нормами публічних галузей права, насамперед адміністративного; приватних прав та інтересів - передусім приватного, цивільного;

6) способом захисту публічного інтересу $є$ інструменти публічного адміністрування, приватного - у порядку, передбаченому главою 3 Цивільного кодексу України;

7) наслідками порушення публічного інтересу буде притягнення до адміністративної або кримінальної відповідальності; приватного - відшкодування шкоди або притягнення до цивільно-правової відповідальності;

8) юридична природа відповідальності за порушення публічного інтересу характеризується накладенням санкцій карного характеру, а за порушення приватного переважно відповідальністю відновлювального характеру.

Схожої думки дотримуються у своєму дослідженні Мельник Р. С., Бевзенко В. М., вважаючи, що під приватними інтересами розуміються ті, що задовольняються власними, винятково інтелектуальними діями й операціями, а також ті, що задовольняються власними фізичними діями, але такими, що не оприлюднюються. На противагу приватним інтересам, на думку цих учених, публічні інтереси поєднують лише ті інтереси, які однаковою мірою $є$ важливими для кожного члена суспільства [23, с. 36$]$.

Із вищевказаного випливає, що під інтересами суспільства та держави під час використання кібернетичного простору доречно вважати важливі для значної кількості суб'єктів цінності (потреби), які відповідно до законодавчо встановленої компетенції мають забезпечуватися суб'єктами публічної адміністрації. У свою чергу, інтереси людини під час використання кіберпростору визначатимуться як усвідомлена учасником інформаційних правовідносин юридично забезпечена в реалізації та її захисті можливість в отриманні певного права.

Зважаючи на це й усвідомлюючи неможливість вичерпної регламентації публічного інтересу при забезпеченні кібербезпеки, все ж важливо, щоб мета правового регулювання використання кібернетичного простору мала демократичний характер, відповідала міжнародним нормам, зокрема положенням ч. 2 ст. 29 Загальної декларації прав людини, згідно з якою при здійсненні своїх прав і свобод кожна людина повинна зазнавати тільки таких обмежень, які встановлені законом виключно з метою забезпечення належного визнання і поваги прав і свобод інших та забезпечення справедливих вимог моралі, громадського порядку і загального добробуту в демократичному суспільстві [24]; договорам, ратифікованим Верховною Радою України; Конституції України, зокрема ст. 3, за якою права і свободи людини та їх гарантії визначають зміст і спрямованість діяльності держави; держава відповідає перед людиною за свою діяльність, а утвердження і забезпечення прав і свобод людини $\epsilon$ головним обов'язком держави [25]; Закону України "Про Основні засади розвитку інформаційного суспільства в Україні на 2007-2015 роки". У пункті 2 частини 3 цього закону зазначено, що при створенні інформаційного законодавства слід керуватися загальними принципами Конституції України, а також базуватися на принципах свободи створення, отримання, використання та розповсюдження інформації; об'єктивності, достовірності, повноти і точності інформації; гармонізації інтересів людини, суспільства та держави в інфрормаційній діяльності; обов'язковості публікації ін- 
формації, яка має важливе суспільне значення; обмеження доступу до інфрормації виключно на підставі закону; мінімізації негативного інформаційного впливу та негативних наслідків функціонування IKT; недопущення незаконного розповсюдження, використання і порушення цілісності інформації; гармонізації інформаційного законодавства і всієї системи вітчизняного законодавства [5].

Отже, захищаючи публічні інтереси, органи публічної адміністрації мають керуватися людино-орієнтованою ідеологією, яка була означена Авер'яновим В. Б., згідно з якою держава має служити інтересам людей, діяти на їхнє благо через усебічне забезпечення пріоритету прав, свобод та інтересів [26].

Спостерігаючи за останніми тенденціями у галузі політики, можна зробити висновки, що Україна відмовляється від такого шляху врегулювання проблем і пропонує створити обмеження для користувачів мережею Інтернет, прийняти спеціальні закони з цього питання. Прикладом можуть служити періодичні намагання легалізувати законопроєкти про регулювання медіа в Україні у частині запровадження оподаткування соціальних мереж, боротьби з дезінформацією та введення відповідальності блогерів за зміст їхніх публікацій.

На нашу думку, необхідно звертатися до європейської практики регулювання діяльності блогерів. Як показує практика пострадянських держав, які вдалися до процедури реєстрації блогерів, закріплення за інтернетпровайдерами та операторами зв'язку обов'язку зберігати не лише факти з'єднання, а й зміст аудіо- та відеопереговорів і листування людей, а також 3 урахуванням останніх не зовсім демократичних тенденцій у сфрері свободи слова у нашій країні, ризик настання негативних наслідків реєстраційних і обмежувальних процесів досить великий. У багатьох західних країнах сумлінні блогери успішно функціонують, розвиваються і сприймаються де-фракто такими суспільствами й без реєстрації.

Зарубіжний досвід. Наприклад, США та Велика Британія, низка європейських країн не мають окремого законодавства для блогерів. А інформаційна діяльність у цих державах регулюється на підставі інформаційного, цивільного, кримінального та іншого законодавства. Прибічники такого способу щодо регулювання їхньої діяльності вважають, що Інтернет має залишитися вільним для обміну інформацією, ідеями, думками без надмірного втручання з боку законодавця.

Така позиція ґрунтується на цілком реальних подіях, які відбувалися у деяких країнах протягом останніх років, зокрема в Росії. У зв'язку з цим Організація з безпеки та співпраці у Європі (ОБСЄ) опублікувала доповідь "Контроль над Інтернетом", присвячену країнам, які вже ввели цензуру в мережі Інтернет або всіляко намагаються це зробити. До таких країн увійшли Білорусь, Грузія, Росія, Китай, Іран, Узбекистан, Казахстан та деякі інші. Згодом до цього переліку може потрапити й Україна.

Судова практика. Погоджуючись із думкою, що суб'єктивне право $є$ мірою можливої поведінки особи, направленої на реалізацію ії інтересу, зазначимо, що досить спірним є твердження, що норми, які захищають інтереси приватних осіб, є лише у приватному праві цивільному, сімейному та інших. Адміністративне право хоча і $€$ галуззю публічного права, також покликане захищати, у тому числі приватні інтереси [27, с. 198-199].

Як зазначає Кунцевич М. П., правовідносини, у яких реалізуються інтереси, передбачають визнання державою і суспільством необхідності в задоволенні певних потреб, а у деяких випадках і способів задоволення цих потреб. До того ж задоволення передбачених у законодавстві потреб зазвичай забезпечується примусовою силою держави. У свою чергу, основним призначенням суб'єктивного права є формальна проголошеність і державна гарантованість можливості людини задовольнити свій інтерес установленим у законі способом [28, с. 13].

Із цього випливає, що інтереси людини під час використання кібернетичного простору, які за своєю суттю $є$ приватними й можуть бути реалізовані у відповідному суб'єктивному праві, захищаються, у тому числі нормами адміністративного права та адміністративного процесуального права.

Так, відповідно до ч. 1 ст. 19 Кодексу адміністративного судочинства України, юрисдикція адміністративних судів поширюється на справи у публічно-правових споpax фрізичних чи юридичних осіб із суб'єктом владних повноважень щодо оскарження його рішень (нормативно-правових актів чи індивідуальних актів), дій чи бездіяльності, крім випадків, коли для розгляду таких спорів законом установлено інший порядок судового провадження. Отже, нормами адміністративного процесуального права регулюються спори, що виникають у публічно-правових відносинах, де один з учасників є суб'єктом владних повноважень, реалізує владні управлінські функції, тобто владно впливає на юридичну чи фрізичну особу (людину), при цьому порушує їх інтереси, права чи свободи в межах публічно-правових відносин [29].

Прикладом такого публічно-правового спору, пов'язаного із використанням кібернетичного простору, може служити позов, поданий Микитою Євстіфєєвим у травні 2017 року до Вищого адміністративного суду України, у якому він просив визнати незаконним і скасувати Указ Президента України від 15 травня 2017 року за № 133/2017 "Про рішення Ради національної безпеки і оборони України від 28 квітня 2017 року "Про застосування персональних спеціальних економічних та інших обмежувальних заходів (санкцій)" у частині введення в дію підпунктів 422, 423, 424, 425 додатка 2 до рішення Ради національної безпеки і оборони України від 15 травня 2017 року (позов про визнання неправомочним указу про заборону російських соціальних мереж).

В обґрунтування своїх вимог позивач посилався на те, що заходи, передбачені спірним Указом, порушують його індивідуальні права як громадянина України та $є$ незаконними, оскільки суперечать Цивільному кодексу України, Закону України "Про інформацію", Закону України "Про санкції", а також порушують його право на інформацію та на свободу вираження поглядів відповідно до ст. 10 Конвенції про захист прав людини та основоположних свобод [30].

Практичне значення отриманих наукових результатів. Одне із практичних значень цього дослідження полягає в окресленні можливої структури кібернетичної безпеки людини через сукупність таких важливих прав та інтересів людини у кібернетичному просторі:

1) Право на широкосмуговий зв'язок (на доступ до мережі Інтернет).

Право на доступ до мережі Інтернет нині стало невід'ємною частиною життя більшості людей, а також важливою основою для реалізації прав та інтересів. Доступ до мережі Інтернет має надаватися за розумну плату та бути недискримінаційним за будь-якими ознаками [31, с. 7].

Для демократії вказане право $є$ фундаментальним i базовим при реалізації інших важливих прав, наприклад права на свободу вираження поглядів [32, с. 669]. Крім того, органами державної влади мають здійснюватися конкретні заходи, спрямовані на забезпечення широкого доступу до мережі Інтернет [31, с. 7].

Варто зазначити, що в Україні право на широкосмуговий зв'язок задеклароване у низці нормативноправових актів, зокрема в Указі Президента України "Про 
заходи щодо розвитку національної складової глобальної інформаційної мережі Інтернет та забезпечення широкого доступу до цієї мережі в Україні", прийнятому 31 липня 2000 року. Відповідно до п. 1 цього нормативно-правового акту розвиток національної складової глобальної інформаційної мережі Інтернет, забезпечення широкого доступу до цієї мережі громадян та юридичних осіб усіх форм власності в Україні, належне представлення в ній національних інформаційних ресурсів $€$ одним із пріоритетних напрямів державної політики у сфері інформатизації, задоволення конституційних прав громадян на інформацію, побудови відкритого демократичного суспільства, розвитку підприємництва.

Основними завданнями щодо розвитку національної складової мережі Інтернет та забезпечення широкого доступу до цієї мережі в Україні було визначено: створення у найкоротші терміни належних економічних, правових, технічних та інших умов для забезпечення широкого доступу громадян, навчальних закладів, наукових та інших установ і організацій усіх форм власності, органів державної влади й органів місцевого самоврядування, суб'єктів підприємницької діяльності до мережі Інтернет [33].

Однак станом на 2019 рік, за даними Офрісу ефективного регулювання, в Україні близько 16 млн абонентів не можуть скористатися 3G- і 4G-зв'язком через відсутність у сільській місцевості відповідних станцій, які проводять сигнал [34].

Також невтішною залишається ситуація, пов'язана із забезпеченням Україною належного рівня кібернетичної безпеки, що підтверджується іï̈ 54 місцем зі 180 країн у Глобальному індексі кібербезпеки у 2018 році [6, с. 34].

2) Право людини на захист персональних даних під час використання кіберпростору, яке полягає в тому, що обробка персональних даних має здійснюватися для конкретних законних цілей, визначених за згодою суб'єкта персональних даних. Також суб'єкт персональних даних має право: знати про джерела збирання, місцезнаходження своїх персональних даних, мету їх обробки, отримувати інформацію про умови надання доступу до персональних даних, зокрема інформацію про третіх осіб, яким передаються його персональні дані тощо [35]. Захист персональних даних людини під час використання кіберпростору стає дедалі актуальнішим питанням, зважаючи на зростання ролі технології хмарних обчислень і зростаючої тенденції зберігати такі дані, як-от: електронна адреса, фотографії, книги, музика й документи у "хмарі" [33, с. 10]. Крім того, персональні дані вважаються своєрідною "валютою" XXI століття, і до існуючих ризиків у цій сфері додались ті, що пов'язані із агресивним нав'язуванням товарів i послуг в обмін на персональні дані людини.

Наприклад, було виявлено, що підрядники Google обманом збирали біометричні дані безхатченків і студентів для поліпшення системи розпізнавання облич смартфона Pixel 4. В обмін на сканування обличчя підрядники пропонували сертифікати на 5 дол. у Starbucks [36]. Існують також ризики, пов'язані з регулярними витоками персональних даних людей. Наприклад, прецедент, який стався із виробником смарт-пристроїв для розумного будинку Wyze щодо витоку даних користувачів. При цьому постраждали клієнти компанії, які використовують гаджети, підключені до інтернету речей (loT). За короткий проміжок часу в мережу потрапили дані 2,4 млн користувачів [37].

3) Право людини на захист від агресивних маркетингових технологій у кіберпросторі, заборона спостереження та (або) моніторингу, у тому числі через файли "cookie", маркери HTTP, HTML5, веб-маяки, модулі роз- пізнавання облич чи інші технології. Використання таких технологій постійного відстеження декларується розробниками різноманітних застосунків як спосіб поліпшення роботи людини в Інтернеті шляхом запам'ятовування іiї уподобань і попередніх переглядів, однак при цьому невідомо якими ще способами ця інформація може бути використана, зокрема при нав'язуванні контекстної реклами чи перетворенні людини із суб'єкта на об'єкт досліджень поза її відома. Фахівці з комп'ютерної безпеки називають таку технологію деперсоналізацією (depersonization), суть якої полягає в тому, що обчислення видаляє користувача із відносин, частково або повністю. Уже існують програми, які виступають від імені людини, наприклад технологія розстановки пріоритетів електронної пошти на основі раніше вистежених уподобань або отримання контекстного оголошення про продаж якогось товару на основі минулої поведінки. У технології Інтернету речей людині не потрібно взагалі взаємодіяти із зовнішніми об'єктами - "розумні" прилади у "розумному" будинку комунікуватимуть між собою без участі людини, а "розумний" автомобіль "взаємодіятиме" з датчиками дорожнього руху та, зрештою, іншими автомобілями [38]. Незважаючи на всі переваги, які надають подібні технології, завжди існуватиме ризик того, що якісь елементи програмного забезпечення будуть наділені непередбачуваними властивостями внаслідок зовнішнього втручання в роботу системи чи неправильної ії експлуатації або що певні елементи міститимуть помилки (баги), що може призвести до непередбачуваних наслідків.

4) Право людини на таємницю електронного листування та спілкування. Це право відповідає праву, закріпленому у ст. 31 Конституції України, за якою кожному гарантується таємниця листування, телефонних розмов, телеграфної та іншої кореспонденції. Винятки можуть бути встановлені лише судом у випадках, передбачених законом, з метою запобігти злочинові чи з'ясувати істину під час розслідування кримінальної справи, якщо іншими способами одержати інформацію неможливо [25].

5) Право на свободу думки і слова, на вільне вираження своїх поглядів і переконань під час використання кібернетичного простору. Таке право кореспондується зі ст. 34 Конституції України, яка закріплює право кожного вільно збирати, зберігати, використовувати і поширювати інформацію усно, письмово або в інший спосіб на свій вибір [25].

У кібернетичному просторі, як і у реальному, людина має право шукати, отримувати й поширювати інформацію та ідеї на свій вибір без будь-якого втручання і незалежно від державних кордонів. Це означає, що людина має право вільно висловлюватися у кібернетичному просторі, у тому числі в мережі Інтернет, і мати доступ до інформації, поглядів, висловлювань інших осіб. Обмежувальні заходи можуть застосовуватися лише згідно з вимогами Європейської конвенції про захист прав людини, а також відповідати законодавству у сфрері прав людини; інтернет-провайдер та провайдер інтернет-контенту і послуг мають поважати права людини, забезпечувати механізми розгляду скарг. Зокрема, людина має право знати, яка інформація щодо неї обробляється на серверах інтернет-провайдерів і операторів зв'язку (інформація про фракти з'єднань, зміст, аудіо- та відеопереговорів, листування тощо) [31, с. 8-9].

6) Право людини на освіту та право на доступ до знань за допомогою використання кіберпростору. Це право може бути реалізовано через онлайн-доступ до освітніх, культурних, наукових, навчальних матеріалів, а також можливість мати доступ до інтерактивної освіти з метою поліпшення цифрової грамотності та підви- 
щення рівня знань. Однак, як виявилось, особливо під час пандемії COVID-19, більшість навчальних закладів України не готові до реалізації цього права, зокрема до дистанційного навчання. Під час онлайн-трансляції у Фейсбуці, присвяченої організації дистанційного навчання, представники Міністерства освіти і науки України висловили рекомендації освітянам розвивати IT-компетентність і зазначили про необхідність роботи над новим положенням про дистанційне навчання. Однак державою при цьому не було забезпечено ні безкоштовних онлайн-консультацій, ні відповідних тренінгів, ні доступу до профрільних електронних ресурсів; не було спеціальним чином організовано самостійну роботу учнів, а також завчасно не впроваджено систему контролю знань. Крім того, нині відсутня єдина платформа, яка би дозволяла організувати дистанційне навчання в Україні. Зрештою, не було також компенсовано витрати, які понесли освітяни, оплачуючи у приватному порядку послуги інтернет-провайдерів [39].

7) Право на забуття (право бути забутим, англ. right to be forgotten) як право людини, яке дозволяє їй вимагати за певних умов видалення своїх персональних даних із загального доступу через пошукові системи, тобто посилань на ті дані, які, на її думку, можуть завдати їй шкоди. Це стосується застарілих, недоречних, неповних, неточних або надлишкових даних чи інформації, законні підстави для зберігання якої зникли із плином часу. Нині це право надзвичайно складно реалізувати в Україні, особливо користуючись послугами електронної комерції, адже на веб-сайтах, які пропонують придбати товари, переважно відсутні технічні можливості для видалення особистого кабінету та персональних даних у них. У свою чергу, адміністратори таких веб-сайтів здебільшого ігнорують вимоги щодо видалення персональних даних клієнтів.

8) Право на ефективний юридичний захист прав та інтересів людини, що пов'язані з використанням кібернетичного простору. Варто зазначити, що нині це право також неможливо реалізувати повною мірою через відсутність в Україні спеціального контролюючого органу у сорері дотримання інформаційних прав. Як зазначає Кушнір І. В., реалізація ефективного контролю у сфері дотримання інформаційних прав неможлива в рамках мандата Омбудсмана. А першою і найважливішою рекомендацією для України $€$ створення незалежного (спеціального) інституту Інформаційного комісара чи комісії, який має бути єдиним органом другої інстанції з розгляду звернень/скарг щодо порушення інформаційних прав [40, с. $79-80]$.

Деякі фахівці виділяють ще таку групу прав, як право на мирні зібрання, об'єднання та участь у кібернетичному просторі, яке реалізується через можливість вільно користуватися технологіями для участі в місцевих, національних, світових публічних обговореннях, бути залученими до процесів електронного урядування, контролю за прийняттям рішень, розподілу ресурсів, підписувати петиції та брати участь у політиці, пов'язаній 3 управлінням мережею Інтернет [31, с. 9].

Зазначимо, що вказаний перелік прав та інтересів людини під час використання кібернетичного простору ґрунтується на аналізі широкого кола профрільної літератури, є оціночним і може доповнюватися у процесі подальших наукових розвідок. До того ж подана в цьому досліджені класифрікація може бути використана при вдосконаленні напрямів адміністративно-правового забезпечення кібернетичної безпеки в Україні, у тому числі для вдосконалення профрільного законодавства України, передусім Закону України "Про основні засади забезпечення кібербезпеки України". Ґрунтуючись на вищевикладеному, на нашу думку, доречно поліпшити визначення терміна "кібербезпека", подавши його у Законі України "Про основні засади забезпечення кібербезпеки України" таким чином: "кібербезпека - сукупність практичних заходів щодо забезпечення захисту життєво важливих прав та інтересів людини, суспільства, держави під час використання кіберпростору, що включає юридичні, технічні та організаційні аспекти". Тобто забезпечення кібербезпеки не обмежується лише захистом інтересів відповідного суб'єкта, завданням уповноважених органів, зокрема публічної адміністрації; має бути також захист прав і свобод людини, держави й суспільства від загроз у кібернетичному просторі.

\section{ВИСНОВКИ}

1. Нині в Україні гостро постала потреба у пошуку способів, засобів і виробленні механізму збалансування життєво важливих інтересів людини, суспільства та держави під час використання кібернетичного простору, які досить часто на практиці конкурують між собою. Адже неузгодженість чи неналежне розв'язання в чинному законодавстві питань збалансування публічних i приватних інтересів може призвести до найгостріших соціально-правових конфліктів [41, с. 525].

2. Під інтересами суспільства та держави під час використання кібернетичного простору доречно вважати важливі для значної кількості суб'єктів цінності (потреби), які відповідно до законодавчо встановленої компетенції мають забезпечуватися суб'єктами публічної адміністрації. При цьому діяльність публічної адміністрації у цій сфрері має бути чітко регламентована законодавством, яке є доступним, точним, ясним і передбачуваним; переслідує законну мету; $є$ необхідним і пропорційним у демократичному суспільстві й забезпечує ефективні засоби правового захисту, тобто таким, що відповідає міжнародному праву, у тому числі Рекомендації CM / Rec (2016) 5 [1] Комітету Міністрів держав-членів щодо Інтернет-свободи [9].

3. Інтереси людини під час використання кіберпростору можна визначити як усвідомлену учасником інформаційних правовідносин юридично забезпечену в реалізації та її захисті можливість в отриманні певного права. Тобто інтереси людини під час використання кібернетичного простору є передусім приватними, можуть бути реалізовані у відповідному суб'єктивному праві й захищаються, у тому числі, нормами адміністративного права. Серед прав та інтересів людини під час використання кібернетичного простору можуть бути: право людини на доступ до мережі Інтернет (або право на широкосмуговий зв'язок); право людини на захист персональних даних під час використання кіберпростору; право людини на таємницю електронного листування та спілкування; право на свободу думки і слова, на вільне вираження своїх поглядів і переконань під час використання кібернетичного простору; право людини на захист від агресивних маркетингових технологій у кіберпросторі, заборона спостереження та (або) моніторингу, у тому числі через файли "cookie", маркери HTTP, HTML5, вебмаяки чи інші технології; право людини на освіту та право на доступ до знань за допомогою використання кіберпростору; право на забуття (право бути забутим, англ. right to be forgotten); право на ефективний засіб юридичного захисту прав та інтересів людини, що пов'язані із використанням кібернетичного простору.

4. Конкретизація інтересів людини, суспільства, держави в галузевих нормативно-правових актах може допомогти в уточненні відповідного об'єкта правового регулювання, що сприятиме також розмежуванню компетенції суб'єктів забезпечення кібербезпеки за предметними і функціональними критеріями, а також пошуку 
ефективних засобів юридичного захисту прав та інтересів людини, що пов'язані з використанням кібернетичного простору. Тобто чітке розуміння того, який саме об'єкт правовідносин підлягає захисту, сприяє пошуку відповідних адекватних способів і засобів його захисту.

\section{Список використаних джерел:}

1. Про рішення Ради національної безпеки і оборони України від 27 січня 2016 року "Про Стратегію кібербезпеки України" : Указ Президента України від 15.03.2016 року № 96/2016. URL: https://zakon5.rada.gov.ua/laws/show/96/2016 (дата звернення: 16.04.2020).

2. Про основні засади забезпечення кібербезпеки України : Закон України від 05.10.2017 року № 2163-VIII. Дата оновлення: 08.07.2018. URL: https://zakon.rada.gov.ua/laws/show/2163-19 (дата звернення: 16.04.2020).

3. Про рішення Ради національної безпеки і оборони України від 29 грудня 2016 року "Про Доктрину інформаційної безпеки України" : Указ Президента України від 25.02.2017 № 47/2017. URL: https://zakon.rada.gov.ua/laws/show/47/2017 (дата звернення: 16.04.2020).

4. Про національну безпеку України : Закон України від 21.06.2018 № 2469-VIII. Дата оновлення: 15.03.2020. URL: https://zakon.rada.gov.ua/ laws/show/2469-19 (дата звернення: 16.04.2020).

5. Про Основні засади розвитку інформаційного суспільства в Україні на 2007-2015 роки: Закон України від 09.02.2007 № 537-V. URL: https://zakon.rada.gov.ua/laws/show/537-16 (дата звернення: 16.04.2020).

6. Плескач М.В. Ключові показники кібернетичної безпеки людини в Україні та їх оцінка. Актуальні проблеми захисту інформаційних прав особи в умовах технологічних викликів та цифрової реальності матеріали міжнародної науково-практичної консреренції. 17-18 вересня 2019 року. С. 33-36.

7. Про введення в дію рішення РНБО України від 28 квітня 2017 року "Про застосування персональних спеціальних економічних та інших обмежувальних заходів (санкцій)" : Указ Президента України від 15.05.2017 року № 133/2017. URL: https://zakon.rada.gov.ua/laws/ show/n0004525-17 (дата звернення: 16.04.2020).

8. Правовий висновок Верховного Суду України про підстави для витребування в добросовісного набувача майна, яке вибуло з володіння держави в незаконний спосіб. URL: https://bg.te.court.gov.ua/ sud1901/pres-centr/7/239579/.

9. Recommendation CM/Rec(2016)5[1] of the Committee of Ministers to member States on Internet freedom (Adopted by the Committee of Ministers on 13 April 2016 at the 1253rd meeting of the Ministers Deputies). URL: https://search.coe.int/cm/pages/result details.aspx?objectid= $09000016806415 f a$.

10. Первомайський О.О. Поняття інтересу в цивільному праві та законодавстві. Юридична Україна. 2014. № 11. С. 53-57.

11. Харитонов $€$ О. Категорія інтересу в цивільному праві України // Актуальні проблеми держави і права : зб. наук. пр. / редкол.: С. В. Ківалов (голов. ред.), Ю. М. Оборотов (заст. голов. ред.), Л. Р. Біла (відп. секр.) [та ін.] ; ОНЮА. Одеса : Юрид. л-ра. 2005. Вип. 25. С. 216-221.

12. Венедіктова І. В. Захист охоронюваних законом інтересів у цивільному праві : автореф. дис. ... д-ра юрид. наук : 12.00 .03 // Київ. нац. ун-т ім. Тараса Шевченка. 2013. 43 с.

13. Самбор М. А. Інтерес в праві: загальнотеоретичні аспекти розуміння та реалізації: автореф. дис ... канд. юрид. наук : 12.00.01 / Микола Анатолійович Самбор. Київ., 2010. 20 с.

14. Словник.UA. Портал української мови та культури: Можливість. URL: https://slovnyk.ua/index.php?swrd=\%D0\%BC\%D0\%BE\%D0\%B6\%D0\% BB\%D0\%B8\%D0\%B2\%D1\%96\%D1\%81\%D1\%82\%D1\%8C

15. Заярний О. А. Правове забезпечення розвитку інформаційно ссери України: адміністративно-деліктний аспект : монографія. Київ: Видавничий дім "Гельветика", 2017. - 700 c. URL: http://ippi.org.ua/sites/ default/files/zayarnii_monografiya_tv_pereplet_0.pdf

16. Словник української мови. Академічний тлумачний словник. URL: http://sum.in.ua/s/potreba

17. Шершеневич Г.Ф. Общая теория права: учебное пособие: В 2 т. М., 1995. Вып. 2, 3, 4. Т. 2. С. 345.

18. Галунько В. В. Публічний інтерес в адміністративному праві. Форум права. 2010. № 4. C. 178-182. URL: http://www.nbuv.gov.ua/ e-journals/FP/2010-4/10gvvvap.pdf.

19. Пришва Н.Ю. Правове регулювання публічних доходів. Вісник Київського національного університету імені Тараса Шевченка. Юридичні науки. 2005. Вип.64. С. 63-64.

20. Коломоєць Т.О. Адміністративний примус у публічному праві України [Текст] : теорія, досвід та практика реалізації. Запорізький держ. ун-т. Запоріжжя : Поліграф. 2004. 403 с.

21. Рішення Конституційного Суду України від 8 квітня 1999 року № 3-рп/99 у справі № 1-1/99. URL: https://zakon.rada.gov.ua/laws/ show/v003p710-99.

22. Адміністративне право України. Повний курс : підручник / Галунько В., Діхтієвський П., Кузьменко О., Стеценко С. та ін. Херсон : ОЛДІ-ПЛЮС, 2018. 446 с

23. Мельник Р. С. Загальне адміністративне право [Текст]: Навчальний посібник / Р. С. Мельник, В. М. Бевзенко. За заг. ред. Р. С. Мельника. К. : Ваіте, 2014. 376 с.]

24. Загальна декларація прав людини від 10.12.1948 року. URL: https://zakon.rada.gov.ua/laws/show/995 015.
25. Конституція України: Закон від 28.06.1996 № 254к/96-ВР. Дата 01.01.2020. URL: https:/zakon rada gov ua/laws/show/ 254\%D0\%BA/96-\%D0\%B2\%D1\%80 (дата звернення: 16.04.2020)

26. Авер'янов В.Б. Людиноцентристська ідеологія як основа реформування українського адміністративного права в умовах інтеграційного процесу. URL: http://radnuk.info/pidrychnuku/493-stetse nko/21414-201206-20-10-58-46.html.

27. Законные интересы как правовая категория : монография / А. В. Малько, В. В. Субочев. С.Пб. : Издательство Р. Асланова "Юридический центр Пресс". 2004. 359 с.

28. Кунцевич М. П. Публічні і приватні інтереси як цінності, що охороняються адміністративним правом. Правовий вісник Української академії банківської справи. 2014. № 2. C. 11-15. URL: http://nbuv.gov.ua/ UJRN/Pvuabs_2014_2_5.

29. Кодекс адміністративного судочинства України : Кодекс від 06.07.2005 № 2747-IV. Дата оновлення: 02.04.2020. URL: https://zakon.rada.gov.ua/laws/show/2747-15 (дата звернення: 16.04.2020).

30. Постанова Вищого адміністративного суду України від 15.11.2017 року у справі №П/800/205/17.

31. Посібник з прав людини для інтернет-користувачів та пояснювальний меморандум (рекомендація $\mathrm{cm} / \mathrm{rec}(2014) 6$ комітету міністрів ради європи державамчленам щодо посібника з прав людини для інтернет-користувачів та пояснювальний меморандум). URL: https://rm.coe.int/16802e3e96.

32. Nicola Lucchi. Access to Network Services and Protection of Constitutional Rights: Recognizing the Essential Role of Internet Access for the Freedom of Expression. URL: https://poseidon01.ssrn.com/ delivery.php?ID=37011502709200912112508802007008509410303303104 102701002202500709609212602611412406705703003906100811602602 708612402406512208704907400304108501612012507107302807100408 302002711503011006808807210307511802610401911608301308606511 $8084011022083104083017 \&$ EXT $=$ pdf

33. Про заходи щодо розвитку національної скпадової глобальної інформаційної мережі Інтернет та забезпечення широкого доступу до цієї мережі в Україні : Указ Президента України від 31 липня 2000 року № 928/2000. URL: https://zakon.rada.gov.ua/laws/show/928/2000 (дата звернення: 16.04.2020).

34. В Україні створять онлайн-карту, яка відображатиме реальне покриття інтернетом. URL: https://www.unian.ua/economics/telecom/ 10696878-v-ukrajini-stvoryat-onlayn-kartu-yaka-vidobrazhatime-realnepokrittya-internetom.html.

35. Про захист персональних даних : Закон України від 01.06.2010 року № 2297-VI. URL: https://zakon.rada.gov.ua/laws/show/2297-17 (дата звернення: 16.04 .2020$)$

36. У Google обманом збирали скани облич. URL: https://ua.news/ ua/v-google-obmanom-sobirali-skany-lits/.

37. В сеть попали данные более 2 млн пользователей устройств для умного дома. URL: https://psm7.com/security/v-set-popali-dannyebolee-2-mln-polzovatelej-ustrojstv-dlya-umnogo-doma.html.

38. Bruce Schneier. SecretsandLies: DigitalSecurityin a NetworkedWorld. URL: https://onlinelibrary.wiley.com/doi/book/10.1002/ 9781119183631

39. Ставлення вчителів до дистанційного навчання. по той бік екрану. http://www.ukr.life/uk/osvita/stavlennya-vchiteliv-do-distantsijnogonavchannya-po-toj-bik-ekranu/.

40. Кушнір І.В. Контролюючий орган України в соері дотримання інформаційних прав: сучасний стан та перспективи розвитку. матеріали міжнародної науково-практичної конференції. 17-18 вересня 2019 року. C. $78-81$

41. Савченко С.В. Співвідношення приватних і публічних інтересів: досвід України. Форум права. 2013. № 3. С. 520-528. URL: http://nbuv.gov.ua/UJRN/FP_index.htm_2013_3_87.

References:

1. Pro rishennia Rady natsionalnoi bezpeky i oborony Ukrainy vid 27 sichnia 2016 roku "Pro Stratehiiu kiberbezpeky Ukrainy" : Ukaz Prezydenta Ukrainy vid 15.03.2016 roku № 96/2016. URL: https://zakon5.rada.gov.ua/laws/show/96/2016 (data zvernennia: 16.04.2020) (in Ukrainian)

2. Pro osnovni zasady zabezpechennia kiberbezpeky Ukrainy : Zakon Ukrainy vid 05.10.2017 roku № 2163-VIII. Data onovlennia: 08.07.2018. URL: https://zakon.rada.gov.ua/laws/show/2163-19 (data zvernennia: 16.04.2020) (in Ukrainian).

3. Pro rishennia Rady natsionalnoi bezpeky i oborony Ukrainy vid 29 hrudnia 2016 roku "Pro Doktrynu informatsiinoi bezpeky Ukrainy" : Ukaz Prezydenta Ukrainy vid 25.02.2017 № 47/2017. URL: https://zakon.rada.gov.ua/laws/show/47/2017 (data zvernennia: 16.04.2020) (in Ukrainian).

4. Pro natsionalnu bezpeku Ukrainy : Zakon Ukrainy vid 21.06.2018 № 2469-VIII. Data onovlennia: 15.03.2020. URL: https://zakon.rada.gov.ua/ laws/show/2469-19 (data zvernennia: 16.04.2020) (in Ukrainian).

5. Pro Osnovni zasady rozvytku informatsiinoho suspilstva $v$ Ukraini na 2007-2015 roky: Zakon Ukrainy vid 09.02.2007 № 537-V. URL: https://zakon.rada.gov.ua/laws/show/537-16 (data zvernennia: 16.04.2020) (in Ukrainian)

6. Pleskach M.V. Kliuchovi pokaznyky kibernetychnoi bezpeky liudyny v Ukraini ta yikh otsinka // Aktualni problemy zakhystu informatsiinykh prav osoby $v$ umovakh tekhnolohichnykh vyklykiv ta tsyfrovoi realnosti [The main indicators of a person's cyber security in Ukraine and and their evaluation]: 
materialy mizhnarodnoi naukovo-praktychnoi konferentsii. 17-18 veresnia 2019 roku. S. 33-36 (in Ukrainian)

7. Pro vvedennia $v$ diiu rishennia RNBO Ukrainy vid 28 kvitnia 2017 roku "Pro zastosuvannia personalnykh spetsialnykh ekonomichnykh ta inshykh obmezhuvalnykh zakhodiv (sanktsii)" : Ukaz Prezydenta Ukrainy vid 15.05.2017 roku № 133/2017. URL: https://zakon.rada.gov.ua/laws/show/ n0004525-17 (data zvernennia: 16.04.2020) (in Ukrainian).

8. Pravovyi vysnovok Verkhovnoho Sudu Ukrainy pro pidstavy dlia vytrebuvannia $v$ dobrosovisnoho nabuvacha maina, yake vybulo $z$ volodinnia derzhavy $v$ nezakonnyi sposib. URL: https://bg.te.court.gov.ua/ sud1901/pres-centr/7/239579/ (in Ukrainian).

9. Recommendation $\mathrm{CM} / \operatorname{Rec}(2016) 5[1]$ of the Committee of Ministers to member States on Internet freedom (Adopted by the Committee of Ministers on 13 April 2016 at the 1253rd meeting of the Ministers' Deputies). URL: https://search.coe.int/cm/pages/result_details.aspx?objectid= $09000016806415 \mathrm{fa}$

10. Pervomaiskyi O.O. Poniattia interesu $v$ tsyvilnomu pravi ta zakonodavstvi [Concept of interest in civil law and legislation] // Yurydychna Ukraina. 2014. № 11. S. 53-57 (in Ukrainian).

11. Kharytonov Ye.O. Katehoriia interesu $v$ tsyvilnomu pravi Ukrainy [Interest in the civil law of Ukraine] // Aktualni problemy derzhavy i prava : zb. nauk. pr. / redkol.: S. V. Kivalov (holov. red.), Yu. M. Oborotov (zast. holov. red.), L. R. Bila (vidp. sekr.) [ta in.] ; ONluA. Odesa : Yuryd. I-ra. 2005. Vyp. 25. S. 216-221 (in Ukrainian)

12. Venediktova I. V. Zakhyst okhoroniuvanykh zakonom interesiv u tsyvilnomu pravi [Protection of interests protected by law in civil law] avtoref. dys. ... d-ra yuryd. nauk : 12.00 .03 // Kyiv. nats. un-t im. Tarasa Shevchenka. 2013. 43 c. (in Ukrainian).

13. Sambor M. A. Interes $v$ pravi: zahalnoteoretychni aspekty rozuminnia ta realizatsii [Interest in law: general theoretical aspects of understanding and implementation]: avtoref. dys ... kand. yuryd. nauk 12.00.01 / Mykola Anatoliiovych Sambor. Kyiv., 2010. 20 s. (in Ukrainian).

14. Slovnyk.UA. Portal ukrainskoi movy ta kultury: Mozhlyvist [Dictionary.UA. Ukrainian Language and Culture Portal: Opportunity]. URL: https://slovnyk.ua/index.php?swrd=\%D0\%BC\%D0\%BE\%D0\%B6\%D0\%BB\% D0\%B8\%D0\%B2\%D1\%96\%D1\%81\%D1\%82\%D1\%8C (in Ukrainian).

15. Zaiarnyi O. A. Pravove zabezpechennia rozvytku informatsiino sfery Ukrainy: administratyvno-deliktnyi aspekt [Legal framework for the development of the information sphere of Ukraine: the administrative and tort]: monohrafiia / O. A. Zaiarnyi. - Kyiv: Vydavnychyi dim "Helvetyka", 2017. - 700 s. URL: http://ippi.org.ua/sites/default/files/zayarnii_ monografiya tv pereplet 0.pdf (in Ukrainian).

16. Slovnyk ukrainskoi movy. Akademichnyi tlumachnyi slovnyk. URL: http://sum.in.ua/s/potreba. (in Ukrainian)

17. Shershenevych H.F. Obshchaia teoryia prava [General Theory of Law]: uchebnoe posobye : V 2 t. M., 1995. Vыp. 2, 3, 4. T. 2. S. 345

18. Halunko V. V. Publichnyi interes $v$ administratyvnomu pravi [Public Interest in Administrative Law] // Forum prava. 2010. № 4. S. 178-182. URL: http://www.nbuv.gov.ua/e-journals/FP/2010-4/10gvvvap.pdf (in Ukrainian).

19. Pryshva N.lu. Pravove rehuliuvannia publichnykh dokhodiv [Legal regulation of Public Income] // Visnyk Kyivskoho natsionalnoho universytetu imeni Tarasa Shevchenka. Yurydychni nauky. 2005. Vyp.64. S. 63-64 (in Ukrainian).

20. Kolomoiets T.O. Administratyvnyi prymus u publichnomu pravi Ukrainy : teoriia, dosvid ta praktyka realizatsii [Administrative coercion in public law of Ukraine: theory, experience and practice]. Zaporizkyi derzh. un-t. Zaporizhzhia : Polihraf. 2004. 403 s. (in Ukrainian).

21. Rishennia Konstytutsiinoho Sudu Ukrainy vid 8 kvitnia 1999 roku № 3-rp/99 u spravi № 1-1/99. URL: https://zakon.rada.gov.ua/laws/ show/v003p710-99 (in Ukrainian).

22. Administratyvne pravo Ukrainy. Povnyi kurs [Administrative law of Ukraine. Full course]: pidruchnyk / Halunko V., Dikhtiievskyi P., Kuzmenko O., Stetsenko S. ta in. Kherson : OLDI-PLluS, 2018. $446 \mathrm{~s}$ (in Ukrainian).

23. Melnyk R. S. Zahalne administratyvne pravo [General administrative law]: Navchalnyi posibnyk / R. S. Melnyk, V. M. Bevzenko. Za zah. red. R. S. Melnyka. K. : Vaite, 2014. 376 s.] (in Ukrainian).

24. Zahalna deklaratsiia prav liudyny vid 10.12 .1948 roku. URL: https://zakon.rada.gov.ua/laws/show/995_015 (in Ukrainian).
25. Konstytutsiia Ukrainy: Zakon vid 28.06.1996 № 254k/96-VR. Data onovlennia: 01.01.2020. URL: https://zakon.rada.gov.ua/laws/show/ $254 \% \mathrm{D} 0 \% \mathrm{BA} / 96-\% \mathrm{D} 0 \% \mathrm{~B} 2 \% \mathrm{D} 1 \% 80$ (data zvernennia: 16.04.2020) (in Ukrainian).

26. Averianov V.B. Liudynotsentrystska ideolohiia yak osnova reformuvannia ukrainskoho administratyvnoho prava $v$ umovakh intehratsiinoho protsesu. URL: http://radnuk.info/pidrychnuku/493-stetse nko/21414-2012-06-20-10-58-46.html (in Ukrainian)

27. Zakonnыe ynteresы kak pravovaia katehoryia : monohrafyia / A. V. Malko, V. V. Subochev. S.Pb. : Yzdatelstvo R. Aslanova "lurydycheskyi tsentr Press". 2004. 359 c. (in Russian)

28. Kuntsevych M. P. Publichni i pryvatni interesy yak tsinnosti, shcho okhoroniaiutsia administratyvnym pravom // Pravovyi visnyk Ukrainskoi akademii bankivskoi spravy. 2014. № 2. S. 11-15. URL: http://nbuv.gov.ua/UJRN/Pvuabs_2014_2_5 (in Ukrainian).

29. Kodeks administratyvnoho sudochynstva Ukrainy : Kodeks vid 06.07.2005 № 2747-IV. Data onovlennia: 02.04.2020. URL: https://zakon.rada.gov.ua/laws/show/2747-15 (data zvernennia: 16.04.2020) (in Ukrainian).

30. Postanova Vyshchoho administratyvnoho sudu Ukrainy vid 15.11.2017 roku u spravi №P/800/205/17 (in Ukrainian).

31. Posibnyk $z$ prav liudyny dlia internet-korystuvachiv ta poiasniuvalnyi memorandum (rekomendatsiia $\mathrm{cm} / \mathrm{rec}(2014) 6$ komitetu ministriv rady yevropy derzhavamchlenam shchodo posibnyka z prav liudyny dlia internetkorystuvachiv ta poiasniuvalnyi memorandum). URL: https://rm.coe.int/16802e3e96 (in Ukrainian).

32. Nicola Lucchi. Access to Network Services and Protection of Constitutional Rights: Recognizing the Essential Role of Internet Access for the Freedom of Expression. URL: https://poseidon01.ssrn.com/ delivery.php?ID=37011502709200912112508802007008509410303303104 102701002202500709609212602611412406705703003906100811602602 708612402406512208704907400304108501612012507107302807100408 302002711503011006808807210307511802610401911608301308606511 $8084011022083104083017 \&$ EXT $=$ pdf

33. Pro zakhody shchodo rozvytku natsionalnoi skladovoi hlobalnoi informatsiinoi merezhi Internet ta zabezpechennia shyrokoho dostupu do tsiiei merezhi v Ukraini : Ukaz Prezydenta Ukrainy vid 31 lypnia 2000 roku № 928/2000. URL: https://zakon.rada.gov.ua/laws/show/928/2000 (data zvernennia: 16.04.2020) (in Ukrainian)

34. V Ukraini stvoriat onlain-kartu, yaka vidobrazhatyme realne pokryttia internetom. URL: https://www.unian.ua/economics/telecom/ 10696878-v-ukrajini-stvoryat-onlayn-kartu-yaka-vidobrazhatime-realnepokrittya-internetom.html (in Ukrainian).

35. Pro zakhyst personalnykh danykh : Zakon Ukrainy vid 01.06.2010 roku № 2297-VI. URL: https://zakon.rada.gov.ua/laws/show/2297-17 (data zvernennia: 16.04.2020) (in Ukrainian).

36. U Google obmanom zbyraly skany oblych. URL: https://ua.news/ua/ v-google-obmanom-sobirali-skany-lits/. (in Russian)

37. V set popaly dannbe bolee $2 \mathrm{mln}$ polzovatelei ustroistv dlia umnoho doma. URL: https://psm7.com/security/v-set-popali-dannye-bolee-2-mlnpolzovatelej-ustrojstv-dlya-umnogo-doma.html (in Russian).

38. Bruce Schneier. SecretsandLies: DigitalSecurityin a NetworkedWorld. URL: https://onlinelibrary.wiley.com/doi/book/10.1002/ 9781119183631

39. Stavlennia vchyteliv do dystantsiinoho navchannia. po toi bik ekranu. http://www.ukr.life/uk/osvita/stavlennya-vchiteliv-do-distantsijnogonavchannya-po-toj-bik-ekranu/ (in Ukrainian).

40. Kushnir I.V. Kontroliuiuchyi orhan Ukrainy v sferi dotrymannia informatsiinykh prav: suchasnyi stan ta perspektyvy rozvytku. materialy mizhnarodnoi naukovo-praktychnoi konferentsii. 17-18 veresnia 2019 roku. S. 78-81 (in Ukrainian).

41. Savchenko S.V. Spivvidnoshennia pryvatnykh i publichnykh interesiv: dosvid Ukrainy // Forum prava. 2013. № 3. S. 520-528. URL: http://nbuv.gov.ua/UJRN/FP_index.htm_2013_3_87 (in Ukrainian).

Received: $27 / 04 / 2020$

1st Revision: $30 / 05 / 2020$

Accepted: 05/06/2020

M. Pleskach, PhD stud.

Taras Shevchenko National University of Kyiv, Kyiv, Ukraine

\section{THE CORRESPONDENCE OF THE PERSON'S, SOCIETY'S AND THE STATE'S IMPORTANT INTERESTS THROUGH THE PRISM OF ADMINISTRATIVE AND LEGAL INSURING OF CYBER SECURITY}

The article is devoted to the issue on balancing the important interests of a person, a society and the state in cyber space by means of administrative law.

The purpose of this article is to determine the legal nature and the role of the correspondence of the important interests of a person, a society and the state in cyber space in the context of administrative and legal provision of cyber security. The paper also deals with a proper balance between the law-enforcement interests of the state and the respect for fundamental human rights.

The method of analysis has revealed in clarifying some features of concepts "interest", "need", "right". The method of synthesis has been used to define common concepts, for example "person's interest in cyberspace". Comparative legal method has been used in the process of comparison of the legislation of Ukraine and the international legislation that governs the issue on balancing the important interests of a person, a society and the state in cyber space.

The author of this research presents the possible structure of person's cyber security through a set of important person's rights and interests in cyberspace, for example, the right to access to the Internet; the right to protect personal data in cyberspace; the right to be protected from aggressive marketing technologies in cyberspace, the prohibition of monitoring, including through cookies, HTTP, HTML5 markers or other technologies; the right to education, the right to access knowledge through the use of cyberspace etc.

Conclusions and proposals of this research can be used for further research and for improving the administrative and information legislation of Ukraine, including the Law of Ukraine "On the Fundamental Principles of Cyber Security of Ukraine".

Keywords: the balance of interests of the person, society and state, cyber space usage, public interest, private interest. 